\title{
SURVEY ON THE DAMSELFLY AND DRAGONFLY FAUNA (INSECTA: ODONATA) OF THE LANDSCAPE OF OUTSTANDING FEATURES "VLASINA"
}

\author{
Aleksandar Đukić ${ }^{1 *}$, Radislav Mirić ${ }^{1}$, Josip Skejo ${ }^{2}$, Saša Rajkov ${ }^{3}$ and Ivan Tot $^{1,4}$ \\ ${ }^{1}$ Scientific Research Society of Biology and Ecology Students "Josif Pančić” \\ Trg Dositeja Obradovića 2, 21000 Novi Sad, Serbia \\ ${ }^{2}$ University of Zagreb, Faculty of Science, Department of Biology, \\ Rooseveltov trg 6, 10000 Zagreb, Croatia \\ ${ }^{3}$ Bulevar Oslobođenja 115/73, 21000 Novi Sad \\ ${ }^{4}$ Association for Sustainable Development and Habitat Protection in Serbia "HabiProt" \\ Bulevar Oslobođenja 106/34, 11040 Belgrade, Serbia \\ *Corresponding author; E-mail: dbe.aleksandar.djukic@student.pmf.uns.ac.rs
}

(Received December 28th, 2018; Accepted March 20th, 2019)

\begin{abstract}
In this paper we present data on damselflies and dragonflies (Insecta: Odonata) of the Landscape of outstanding features (LOF) "Vlasina". Most of the data were collected during research camps of the Scientic Research Society of Biology and Ecology Students "Josif Pančić" that took place from 2013 to 2018, when 27 Odonata species were recorded. If this research is combined with previously published data, 37 species of damselflies and dragonflies were recorded in Landscape of Outstanding Features "Vlasina". The paper presents distribution and reproduction status of the recorded species, as well as their diversity in this area. The most important species is Epitheca bimaculata (Charpentier, 1825), because Vlasina represents one of its southernmost and highest habitats in Europe. For Sympetrum flaveolum (Linnaeus, 1758) Vlasina is one of the most important habitats in Serbia, as well as for Leucorrhinia pectoralis (Charpentier, 1825) which is Natura 2000 species.
\end{abstract}

Key words: Epitheca bimaculata, Leucorrhinia pectoralis, damselflies and dragonflies, Natura 2000, Vlasina Lake.

\section{INTRODUCTION}

Vlasina plateau is located in the southeast of Serbia, close to the Bulgarian border. The plateau is surrounded by mountains Vardenik, Gramada and Veliki Čemernik, with Besna Kobila, Dukat and Ruj in their vicinity, representing northwestern branches of the Rhodope mountain range. This area is characterized by a harsh continental climate, partly changed after construction of the dam that formed artificial water accumulation "Vlasina Lake" (RANĐELOVIĆ and ZlatKOVIĆ, 2010; BELIJ, 2014). 
Specific biodiversity of the Vlasina region was primarily recognized by botanists, whose research started back in the $19^{\text {th }}$ century with the great naturalist (eminent botanist and zoologist) Josif Pančić (1814-1888), who described four plant species new to science (BELIJ, 2014). Further botanical research was continued and produced precise data on the presence of 956 plant taxa (RANĐELOVIĆ and ZLATKOVIĆ, 2010). Unlike plants that have been well studied both before and after the construction of the dam, animals have been rarely subject of the research. Among vertebrates, more than 150 species of birds were registered on Vlasina plateau (PuZOVić et al., 2009), as well as around 16 species of fish (SIMONOVIĆ and NiKOLIĆ, 1996), and 12 species of reptiles and amphibians (DINOV and CRNOBRNJA ISAILOVIĆ, 2013). Results of the research on entomofauna (Orthoptera, Lepidoptera, Heteroptera, Diptera: Syrphidae), indicate the presence of large number of endemic, relict and endangered species (PAVIĆEVIĆ et al., 2014; SKEJO and IVKOVIĆ, 2015; Tot et al., 2015; VuJIĆ et al., 2016; ŠEAT, 2017; Tot et al., 2018). First data on damselflies and dragonflies from Vlasina were given by ADAMOVIĆ (1949) who listed 20 species for the area. Further data were collected only recently, at the end of the $20^{\text {th }}$ and the beginning of this century (ANDJUS, 1992; SANTOVAC et al., 2005; JOVIĆ et al., 2009).

Tradition of damselflies and dragonflies research in Serbia is long. Most of the data originate from the Province of Vojvodina in the north (JOVIĆ et al., 2009; RAJKOV, 2014; RAJKOV et al., 2012), while research in the central and southern Serbia is lagging behind. JOVIĆ (2013) listed 67 Odonata species in Serbian fauna, among which four were historical records. Insufficient data make inadequate basis for declaring species with the priority for protection (Jović et al., 2009). Although large-scale grid distribution maps exist for all European species (BOUdOT et al., 2009; BOUdOT and KALKMAN, 2015), for most species there are still no detailed distribution maps and few data on habitat requirements are known. Therefore, the status of vulnerability of such species cannot be assessed (RAJKOV, 2014).

Our knowledge on damselflies and dragonflies in protected areas in Serbia is limited. So far, there have been only a few publications on damselflies and dragonflies inhabiting specific protected areas: Special Nature Reserve "Obedska Bara" (ADAMOVIĆ and ANĐUS, 1983), SNR "Krupačko blato" (ADAMOVIĆ, 1993), SNR "Stari Begej - Carska bara" (SANTOVAC and ANĐUS, 1995-98), SNR "Zasavica" (JoviĆ et al., 2007, RAJKOV and Š́́IBAN, 2012), Landscape of outstanding features (LOF throughout hereafter) "Ovčarsko-kablarska klisura" (RAJKOV, 2016).

The aim of this study was to determine Odonata diversity in the Landscape of outstanding features (LOF) "Vlasina" and to determine reproduction status of the recorded species.

\section{MATERIALS AND METHODS}

Landscape of outstanding features "Vlasina" consists of Vlasina plateau which has an artificial lake in its center. The lake is a result of the construction of the dam (from 1949 to 1954) in the northern part of a former mire Vlasinsko Blato (BELI, 2014). Former mire covered an area of approximately 500 ha, while now, as most of it is submerged, it covers only 30 ha exhibiting a 1-3.5 m thick peat deposit. That means that most of the huge area having originally some primary habitats with relict and boreal character has been destroyed. What was left of Vlasina mire are just small or medium sized areas in valleys of the lake tributaries and on peat islands. Submerging caused several changes in the ecosystem, one of most prominent being climate change. Forming of the lake with plenty of water $\left(168^{x} 10^{6} \mathrm{~m}^{3}\right)$ significantly changed local climate, for mean annual temperature decreased by $1.1{ }^{\circ} \mathrm{C}$ and mean precipitation from $838 \mathrm{~mm}$ to $722.9 \mathrm{~mm}$ (RANĐELOVIĆ and ZLATKOVIĆ, 2010). According to the available data from the 1960s, the water level in the lake fluctuates yearly up 
to $3.59 \mathrm{~m}$ - from around 1210-1211 m a.s.l., during winter to cc. $1208 \mathrm{~m}$ a.s.l, during summer (STANKOVIĆ, 1970). However, maintenance of the dam within the last few years of our study resulted in water level of the lake falling (at least) as low as $1206.5 \mathrm{~m}$ a.s.l. (KocIĆ, 2018)

Field surveys were carried out on the lake itself and on its coastal area, as well as along small rivers and in other habitats within the LOF "Vlasina" (Fig. 1). List of localities with altitude and coordinates is given in Tab. 1.

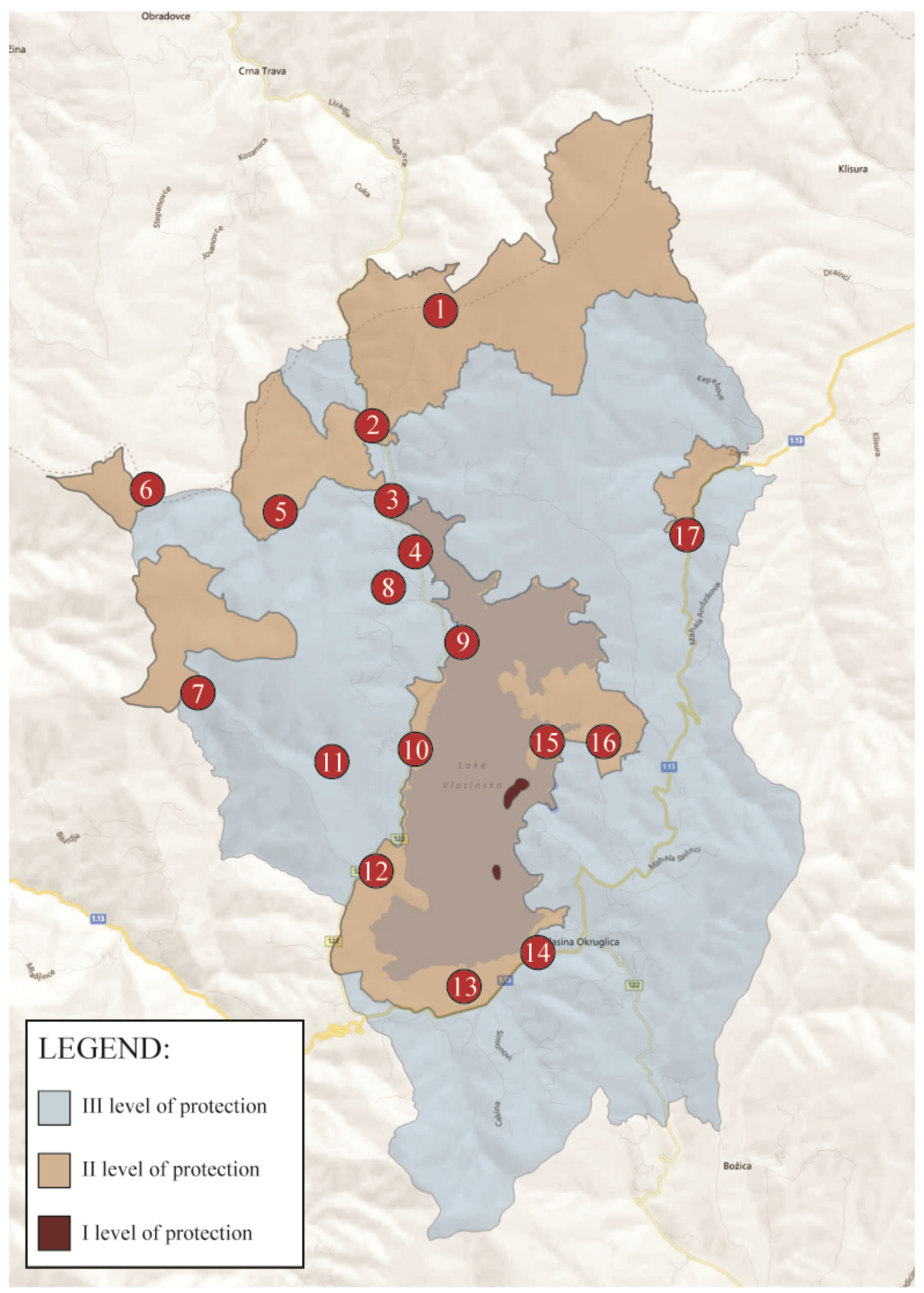

Figure 1. Landscape of outstanding features "Vlasina" with studied localities 1. Polomska čuka; 2. River Vlasina; 3. Elektransko odmaralište; 4. Hotel Vlasina; 5. Gadžini Srednja reka; 6. Mali Čemernik; 7. Kula; 8. Vlasina Rid; 9. Vlasina Rid (lake shoreline); 10. Ljote; 11. Paljina; 12. Delnice; 13. Blato; 14. Božički kanal; 15. Dugi del; 16. Murina reka; 17. Vučja reka. 
Table 1. A list of studied localities with geographical coordinates and elevation

\begin{tabular}{|c|c|c|c|}
\hline Locality number & Locality & Elevation $(\mathrm{m})$ & Geographical coordinates \\
\hline 1. & Polomska čuka & 1470 & $42^{\circ} 46^{\prime} 35^{\prime \prime} \mathrm{N}, 22^{\circ} 20^{\prime} 06^{\prime \prime E}$ \\
\hline 2. & River Vlasina & 1187 & $42^{\circ} 45^{\prime} 32^{\prime \prime N}, 22^{\circ} 19^{\prime} 13^{\prime \prime} \mathrm{E}$ \\
\hline 3. & Elektransko odmaralište & 1223 & $42^{\circ} 44^{\prime} 51^{\prime \prime} \mathrm{N}, 22^{\circ} 19^{\prime} 30^{\prime \prime} \mathrm{E}$ \\
\hline 4. & Hotel Vlasina & 1227 & $42^{\circ} 44^{\prime} 24^{\prime \prime N}, 22^{\circ} 19^{\prime} 47^{\prime \prime} \mathrm{E}$ \\
\hline 5. & Gadžini, Srednja reka & 1427 & $42^{\circ} 44^{\prime} 45^{\prime \prime} \mathrm{N}, 22^{\circ} 18^{\prime} 07^{\prime \prime} \mathrm{E}$ \\
\hline 6. & Mali Čemernik & 1540 & $42^{\circ} 44^{\prime} 58^{\prime \prime} \mathrm{N}, 22^{\circ} 16^{\prime} 28^{\prime \prime} \mathrm{E}$ \\
\hline 7. & Kula & 1470 & $42^{\circ} 43^{\prime} 07^{\prime \prime} \mathrm{N}, 22^{\circ} 17^{\prime} 06^{\prime \prime} \mathrm{E}$ \\
\hline 8. & Vlasina Rid & 1275 & $42^{\circ} 44^{\prime} 04^{\prime \prime N}, 22^{\circ} 19^{\prime} 27^{\prime \prime} \mathrm{E}$ \\
\hline 9. & Vlasina Rid (lake shoreline) & 1207 & $42^{\circ} 43^{\prime} 35^{\prime \prime} \mathrm{N}, 22^{\circ} 20^{\prime} 20^{\prime \prime} \mathrm{E}$ \\
\hline 10. & Ljote & 1220 & $42^{\circ} 42^{\prime} 37^{\prime \prime} \mathrm{N}, 22^{\circ} 19^{\prime} 46^{\prime \prime} \mathrm{E}$ \\
\hline 11. & Paljina & 1315 & $42^{\circ} 42^{\prime} 30^{\prime \prime} \mathrm{N}, 22^{\circ} 18^{\prime} 45^{\prime \prime} \mathrm{E}$ \\
\hline 12. & Delnice & 1223 & $42^{\circ} 41^{\prime} 30^{\prime \prime} \mathrm{N}, 22^{\circ} 19^{\prime} 18^{\prime \prime} \mathrm{E}$ \\
\hline 13. & Blato & 1228 & $42^{\circ} 40^{\prime} 27^{\prime \prime N}, 22^{\circ} 20^{\prime} 24^{\prime \prime} \mathrm{E}$ \\
\hline 14. & Božički kanal & 1223 & $42^{\circ} 40^{\prime} 45^{\prime \prime} \mathrm{N}, 22^{\circ} 21^{\prime} 17^{\prime \prime} \mathrm{E}$ \\
\hline 15. & Dugi del & 1119 & $42^{\circ} 42^{\prime} 40^{\prime \prime} \mathrm{N}, 22^{\circ} 21^{\prime} 25^{\prime \prime} \mathrm{E}$ \\
\hline 16. & Murina reka & 1227 & $42^{\circ} 42^{\prime} 39^{\prime \prime} \mathrm{N}, 22^{\circ} 22^{\prime} 07^{\prime \prime} \mathrm{E}$ \\
\hline 17. & Vučja reka & 1050 & $42^{\circ} 44^{\prime} 32^{\prime \prime} \mathrm{N}, 22^{\circ} 23^{\prime} 09^{\prime \prime} \mathrm{E}$ \\
\hline
\end{tabular}

Research has been carried out from 14.07.2013 till 08.09.2018 and organized by Entomology section of the Scientic Research Society of Biology and Ecology Students "Josif Pančić" (Novi Sad, Serbia) and by the Association for Sustainable Development and Habitat Protection in Serbia "HabiProt" (Belgrade, Serbia). Josip Skejo was involved as a visiting student from the Biology students association - BIUS (Zagreb). Information on the number of species and their individual abundance was ususally collected by observing adult insects. Research was not performed systematically. The data were gathered during spring, summer and autumn and visists to listed localities were not evenly distributed throughout the season.

For every Odonata species that was recorded during research, reproductive indices were registered on the basis of gathered data on exuviae and teneral individuals and reproductive behaviour of adults (territoriality, copula, oviposition).

Four categories were defined, based on the British Dragonfly Society's Odonata breeding criteria (DAGUET et al. 2008) with some modification:

1. Successful breeding - confirmed - exuviae or tenerals (freshly emerged individuals, still incapable of flight), found on or near water body.

2. Successful breeding - probable - reasonable number of individuals of both sexes recorded regularly and/or reproductive behavior (oviposition) recorded on the water surface at or in close proximity of a water body with habitat characteristics favourable for the species.

3. Possible breeding - pair copulating or female seen at a water body suitable for the species where at least one male has been observed to be engaged in some form of reproductive behaviour, such as territoriality or pursuing females

4. No sign of reproduction - only one or a few adult individuals recorded, with no sign of reproduction.

When necessary, damselflies and dragonflies were captured by entomological net. Individuals were identified by observation using manual magnifying glass $(\approx 10 \mathrm{x}$ magnification), characters important for identification were photographed, and only in some cases individuals were collected and examined under binocular in laboratory. None of the species protected by the Serbian Code of regulations on the declaration and protection of 
strictly protected and protected wild species of plants, animals and fungi was sampled (OGRS, 2010).

Identification was done based on Odonata identification guide for Europe (DIJKSTRA and LEWINGTON, 2006). All data have been added in online database Alciphron (ĐuKIĆ, 2014).

\section{RESULTS}

During the research, 27 species of damselflies and dragonflies were recorded and presence of teneral individuals and reproductive behavior were observed (Tab. 2). Reproduction was confirmed for 8 species of damselflies and dragonflies. If we include species with probable reproduction, we reach a total of 12 species (44\%) with confirmed or probable reproduction.

Table 2. List of Odonata species of LOF "Vlasina" with recorded activity

\begin{tabular}{|c|c|c|}
\hline Species & $\begin{array}{c}\text { Activity } \\
\text { Ter/Cop/Ovi/ } \\
\text { /Ten/Exu }\end{array}$ & $\begin{array}{c}\text { Reproduction } \\
\text { status }\end{array}$ \\
\hline Calopteryx splendens (Harris, 1782) & & - \\
\hline Lestes barbarus (Fabricius, 1798) & & - \\
\hline Coenagrion puella (Linnaeus, 1758) & & - \\
\hline Enallagma cyathigerum (Charpentier, 1840) & Cop, Ten & $\bullet$ \\
\hline Erythromma najas (Hansemann, 1823) & Cop & o \\
\hline Ischnura elegans (Vander Linden, 1820) & Cop & ० \\
\hline Pyrrhosoma nymphula (Sulzer, 1776) & & - \\
\hline Platycnemis pennipes (Pallas, 1771) & Cop, Ten & $\bullet$ \\
\hline Aeshna cyanea (Muller, 1764) & Ter & + \\
\hline Anax imperator Leach, 1815 & & - \\
\hline Cordulegaster bidentata Selys, 1843 & Ter, Cop & + \\
\hline Cordulia aenea (Linnaeus, 1758) & Ter & + \\
\hline Epitheca bimaculata (Charpentier, 1825) & Ten, Exu & $\bullet$ \\
\hline Gomphus vulgatissimus (Linnaeus, 1758) & & $\bullet$ \\
\hline Onychogomphus forcipatus (Linnaeus, 1758) & & - \\
\hline Crocothemis erythraea (Brullé, 1832) & & - \\
\hline Libellula depressa Linnaeus, 1758 & Cop, Ovi & ○ \\
\hline Libellula quadrimaculata Linnaeus, 1758 & Cop, Ovi & ० \\
\hline Orthetrum albistylum (Selys, 1848) & & - \\
\hline Orthetrum brunneum (Fonscolombe, 1837) & Cop, Ten & $\bullet$ \\
\hline Orthetrum cancellatum (Linnaeus, 1758) & Ten & $\bullet$ \\
\hline Sympetrum flaveolum (Linnaeus, 1758) & Cop, Ten & $\bullet$ \\
\hline Sympetrum fonscolombii (Selys, 1840) & & - \\
\hline Sympetrum meridionale (Selys, 1841) & & - \\
\hline Sympetrum sanguineum (Muller, 1764) & Ten & $\bullet$ \\
\hline Sympetrum striolatum (Charpentier, 1840) & & - \\
\hline Sympetrum vulgatum (Linnaeus, 1758) & & - \\
\hline
\end{tabular}

Ter - Territoriality, Cop - Copula, Ovi - Oviposition, Ten - Teneral.

- Successful breeding confirmed, o Successful breeding probable,

+ Possible breeding, - No sign of reproduction.

Records of all species registered during our research are listed below. 


\section{SUBORDER ZYGOPTERA}

\section{Family Calopterygidae}

1. Calopteryx splendens (Harris, 1780): Hotel Vlasina 20 - 25. 07. 2015. leg. I. Tot, R. Mirić; Vlasina Rid 11. 07. 2017. leg. A. Đukić, M. Nikolić; Gadžini, Srednja reka 29. 07. 2018. leg. I. Tot.

\section{Family Lestidae}

2. Lestes barbarus (Fabricius, 1798): Blato 27. 07. 2018. R. Mirić, T. Rekecki, N. Veljković, B. Matić.

\section{Family Coenagrionidae}

3. Coenagrion puella (Linnaeus, 1758): Blato 15. 07. 2014. leg. S. Hudak, A. Milutinović; Hotel Vlasina 20 - 25. 07. 2015. leg. I. Tot, R. Mirić; Vlasina Rid (lake shoreline) 11. 07. 2017. leg. A. Đukić, M. Nikolić; Hotel Vlasina 12. 07. 2017. leg. A. Đukić, M. Nikolić; Murina reka 14. 07. 2017. leg. A. Đukić.

4. Enallagma cyathigerum (Charpentier, 1840): Hotel Vlasina 14. 07. 2013. leg. I. Tot; Blato 14. 07. 2014. leg. D. Rajković; Blato 14. 07. 2014. leg. S. Hudak, A. Milutinović; Blato 16. 07. 2014. leg. A. Milutinović; Elektransko odmaralište 17. 07. 2014. leg. J. Skejo; Elektransko odmaralište 17. 07. 2014. leg. S. Hudak; Dugi del 19. 07. 2014. leg. A. Milutinović; Elektransko odmaralište 19. 07. 2014. leg. S. Hudak, A. Milutinović; Murina reka 19. 07. 2014. leg. S. Hudak; Hotel Vlasina 20 - 25. 07. 2015. leg. I. Tot, R. Mirić; Božički kanal 13. 07. 2016. leg. M. Popović; Vlasina Rid 11. 07. 2017. leg. A. Đukić, M. Nikolić; Hotel Vlasina 12. 07. 2017. leg. A. Đukić i M. Nikolić; Murina reka 14. 07. 2017. leg. A. Đukić; Hotel Vlasina 16. 07. 2017. leg. A. Đukić, M. Nikolić; Božički kanal 06. 10. 2017. leg. A. Đukić, M. Gajić; Ljote 27. 05. 2018. B. Nadaždin; Božički kanal 27. 05. 2018. S. Stevčić .

5. Erythromma najas (Hansemann, 1823): Blato 15. 07. 2014. S. Hudak; Hotel Vlasina 17. 07. 2014. S. Hudak; Hotel Vlasina 20 - 25. 07. 2015. leg. I. Tot, R. Mirić; Murina reka 14. 07. 2017. leg. A. Đukić; Hotel Vlasina 16. 07. 2017. leg. A. Đukić, M. Nikolić; Vlasina Rid (lake shoreline) 17. 07. 2017. leg. A. Đukić, M. Nikolić; Blato 27. 07. 2018. leg. R. Mirić, T. Rekecki, N. Veljković, B. Matić, M. Radoman .

6. Ischnura elegans (Vander Linden, 1820): Hotel Vlasina 20 - 25. 07. 2015. leg. I. Tot, R. Mirić; Vlasina Rid (lake shoreline) 11. 07. 2017. leg. A. Đukić, M. Nikolić; Hotel Vlasina 12. 07. 2017. leg. A. Đukić, M. Nikolić; Blato 27. 07. 2018. leg. R. Mirić, T. Rekecki, N. Veljković, B. Matić, M. Radoman.

7. Pyrrhosoma nymphula (Sulzer, 1776): Hotel Vlasina 20 - 25. 07. 2015. leg. I. Tot, R. Mirić; Hotel Vlasina 12. 07. 2017. leg. A. Đukić, M. Nikolić; River Vlasina 12. 07. 2017. leg. A. Đukić, M. Nikolić.

\section{Family Platycnemididae}

8. Platycnemis pennipes (Pallas, 1771): Blato 15. 07. 2014. leg. S. Hudak; Elektransko odmaralište 17. 07. 2014. leg. S. Hudak; Hotel Vlasina 18. 07. 2014. leg. S. Hudak; Hotel Vlasina 20 - 25. 07. 2015. leg. I. Tot, R. Mirić; Hotel Vlasina 12. 07. 2017. leg. A. Đukić, M. Nikolić; Murina reka 14. 07. 2017. leg. A. Đukić; River Vlasina 26. 07. 2018. leg. T. Tot; Hotel Vlasina 08. 09. 2018. S. Stevčić. 


\section{SUBORDER ANISOPTERA}

\section{Family Aeshnidae}

9. Aeshna cyanea (Müller, 1764): Hotel Vlasina 20 - 25. 07. 2015. leg. I. Tot, R. Mirić; Gadžini Srednja reka 04. 09. 2016. leg. I. Tot; Paljina 04. 09. 2016. leg. J. Koturov; Elektransko odmaralište 08. 09. 2016. leg. I. Tot; River Vlasina 26. 07. 2018. leg. T. Tot.

10. Anax imperator Leach, 1815: Elektransko odmaralište 17. 07. 2014. leg. S. Hudak; Hotel Vlasina 20 - 25. 07. 2015. leg. I. Tot, R. Mirić; Blato 27. 07. 2018. leg. R. Mirić, T. Rekecki, N. Veljković, B. Matić, M. Radoman.

\section{Family Cordulegastridae}

11. Cordulegaster bidentata Selys, 1843: Vučja reka 13. 07. 2017. leg. A. Đukić; Polomska čuka 15. 07. 2017. leg. M. Vujić.

\section{Family Corduliidae}

12. Cordulia aenea (Linnaeus, 1758): Hotel Vlasina 20 - 25. 07. 2015. leg. I. Tot, R. Mirić; Murina reka 14. 07. 2017. leg. A. Đukić; Hotel Vlasina 16. 07. 2017. leg. A. Đukić, M. Nikolić.

13. Epitheca bimaculata (Charpentier, 1825): Elektransko odmaralište 19. 07. 2014. leg. J. Skejo; Hotel Vlasina 20 - 25. 07. 2015. leg. I. Tot, R. Mirić; Elektransko odmaralište 12. 06. 2016. leg. M. Đurić; Vlasina Rid (lake shoreline) 19. 05. 2017. leg. M. Vujić; Vlasina Rid (lake shoreline) 11. 07. 2017. leg. A. Đukić, M. Nikolić; Vlasina Rid (lake shoreline) 25. 05. 2018. leg. A. Petričević; Blato 27. 05. 2018. B. Nadaždin; Blato 27. 07. 2018. leg. R. Mirić, T. Rekecki, N. Veljković, B. Matić, M. Radoman .

\section{Family Gomphidae}

14. Gomphus vulgatissimus (Linnaeus, 1758): Vlasina Rid (lake shoreline) 29.05.2011. leg. S. Rajkov; Hotel Vlasina 12. 07. 2017. leg. A. Đukić i M. Nikolić.

15. Onychogomphus forcipatus (Linnaeus, 1758): Mali Čemernik 07. 07. 2016. leg. M. Đurić.

\section{Family Libellulidae}

16. Crocothemis erythraea (Brullé, 1832): Hotel Vlasina 20 - 25. 07. 2015. leg. I. Tot, R. Mirić.

17. Libellula depressa Linnaeus, 1758: Hotel Vlasina 18. 07. 2013. leg. I. Tot; Hotel Vlasina 20 - 25. 07. 2015. leg. I. Tot, R. Mirić; Gadžini Srednja reka 07. 07. 2016. leg. M. Đurić; Hotel Vlasina 12. 07. 2017. leg. A. Đukić, M. Nikolić; Vučja reka 13. 07. 2017. leg. A. Đukić, T. Tot; Murina reka 14. 07. 2017. leg. A. Đukić; Kula 19. 05. 2017. leg. I. Tot, Mali Čemernik 28. 07. 2018. leg I. Tot.

18. Libellula quadrimaculata Linnaeus, 1758: Hotel Vlasina 20 - 25. 07. 2015. leg. I. Tot, R. Mirić; Hotel Vlasina 12. 07. 2017. leg. A. Đukić, M. Nikolić; Murina reka 14. 07. 2017. leg. A. Đukić; Hotel Vlasina 16. 07. 2017. leg. A. Đukić, M. Nikolić .

19. Orthetrum albistylum (Selys, 1848): Hotel Vlasina 20 - 25. 07. 2015. leg. I. Tot, R. Mirić; Gadžini Srednja reka 07. 07. 2016. leg. M. Đurić.

20. Orthetrum brunneum (Fonscolombe, 1837): Vlasina Rid (lake shoreline) 11. 07. 2017. leg. A. Đukić, M. Nikolić; Blato 27. 07. 2018. leg. R. Mirić, T. Rekecki, N. Veljković, B. Matić, M. Radoman; Ljote 28. 07. 2018. leg. R. Mirić, M. Radoman.

21. Orthetrum cancellatum (Linnaeus, 1758): Hotel Vlasina 18. 07. 2013. leg. I. Tot; Blato 15. 07. 2014. A. Milutinović; Elektransko odmaralište 17. 07. 2014. A. Milutinović; Hotel 
Vlasina 20 - 25. 07. 2015. leg. I. Tot, R. Mirić; Gadžini Srednja reka 07. 07. 2016. leg. M. Đurić; Hotel Vlasina 12. 07. 2017. leg. A. Đukić, M. Nikolić; Murina reka 14. 07. 2017. leg. A. Đukić; Elektransko odmaralište 28. 05. 2018. B. Nadaždin; Blato 27. 07. 2018. leg. R. Mirić, T. Rekecki, N. Veljković, B. Matić, M. Radoman; Ljote 28. 07. 2018. leg. R. Mirić, M. Radoman; Elektransko odmaralište 24. 08. 2018. M. Đurić.

22. Sympetrum flaveolum (Linnaeus, 1758): Blato 15. 07. 2014. leg. S. Hudak; Blato 16. 07. 2014. leg. S. Hudak; Ljote 20 - 25. 07. 2015. leg. I. Tot, R. Mirić; Hotel Vlasina 12. 07. 2017. leg. A. Đukić, M. Nikolić; Božički kanal 13. 07. 2016. leg. M. Popović; Hotel Vlasina 14. 07. 2017. leg I. Tot; Hotel Vlasina 16. 07. 2017. leg. A. Đukić, M. Nikolić; Blato 27. 07. 2018. leg. R. Mirić, T. Rekecki, N. Veljković, B. Matić, M. Radoman; Ljote 28. 07. 2018. leg. R. Mirić, M. Radoman; Delnice 29. 07. 2018. leg. R. Mirić, M. Radoman.

23. Sympetrum fonscolombii (Selys, 1840); Delnice 29.07.2018. leg. R. Mirić, M. Radoman; Delnice 07. 09. 2018. S. Stevčić.

24. Sympetrum meridionale (Selys, 1841): Blato 06. 10. 2017. leg. A. Đukić, M. Maričić.

25. Sympetrum sanguineum (Müller, 1764): Blato 16. 07. 2014. S. Hudak; Hotel Vlasina 17. 07. 2014. S. Hudak; Hotel Vlasina 20 - 25. 07. 2015. leg. I. Tot, R. Mirić; Blato 16. 07. 2017. leg. A. Đukić, M. Nikolić; Elektransko odmaralište 17. 07. 2017. leg. A. Đukić, M. Nikolić.

26. Sympetrum striolatum (Charpentier, 1840): Blato 06. 10. 2017. leg. A. Đukić, I. Bolesnikov.

27. Sympetrum vulgatum (Linnaeus, 1758): Hotel Vlasina 20 - 25. 07. 2015. leg. I. Tot, R. Mirić; Blato 06. 10. 2017. leg. A. Đukić, M. Vujić.

\section{DISCUSSION}

Data on the fauna of Odonata of the LOF "Vlasina" were and are still insufficient. Until now, 23 species had been recorded in four studies (ADAMOVIĆ 1949; ANDJUS, 1992; SANTOVAC et al., 2005; Jović et al., 2009). Of 27 Odonata species recorded in our research, 13 had been also previously reported in the literature, while 14 species are new for the investigated area. Together with the previously published data, we compile a preliminary list of 37 species recorded in this area (Tab 3).

\section{Comments on the most noteworthy species}

\section{Epitheca bimaculata}

After the last sighting in 1906 in the village of Rogot, Epitheca bimaculata was rediscovered in 2001 in Serbia (JoviĆ and ANDJUS, 2003). In the following period, the species was found in several locations across Serbia, and the reproduction was confirmed by the exuviae and freshly emerged adults. Although predominantly lacustrine species - inhabiting mesotrophic to eutrophic lakes with much submerged and floating vegetation, relatively deep lakes that are partly or completely surrounded by trees or bushes (DIJKSTRA and LEWINGTON, 2006), E. bimaculata has also been found in wetland habitats and on the shores of the slowmoving river Zasavica (RAJKOV and ŠĆIBAN, 2012).

Epitheca bimaculata (Fig. 2) is a predominantly a lowland species in Europe. There are certain higher areas in Switzerland where this species is breeding, the highest of all being at the Lac des Taillères (Taillères lake) on the Jura Plateau at an altitude of $1036 \mathrm{~m}$ (MonNERAT, 2005). The record of E. bimaculata at locality No. 4: Hotel Vlasina at an altitude of $1225 \mathrm{~m}$ is the highest breeding locality of the species in Europe. The first discovery in LOF "Vlasina" was on July 19, 2014 at locality No. 3: Elektransko odmaralište, when 
teneral specimens and exuviae were found (Fig. 3-4), confirming the species reproduction at the location.

Table 3. List of Odonata species recorded in the LOF "Vlasina" based on previously published data and results of this research

\begin{tabular}{|c|c|}
\hline Suborder ZYGOPTERA & Suborder ANISOPTERA \\
\hline Fam. Calopterygidae & $\begin{array}{c}\text { Fam. Aeshnidae } \\
\end{array}$ \\
\hline Calopteryx splendens (Harris, 1782)** & Aeshna affinis Vander Linden, 1820* \\
\hline Calopteryx virgo (Linnaeus, 1758)* & Aeshna cyanea (Müller, 1764) \\
\hline Fam. Lestidae & Anax imperator Leach, 1815 \\
\hline Lestes dryas Kirby, $1890^{*}$ & Fam. Cordulegastridae \\
\hline Lestes barbarus (Fabricius, 1798) & Cordulegaster bidentata Selys, 1843 \\
\hline Lestes sponsa (Hansemann, 1823)* & Fam. Corduliidae \\
\hline $\begin{array}{l}\text { Chalcolestes viridis (Vander Linden, } \\
1825)^{*}\end{array}$ & Cordulia aenea (Linnaeus, 1758)** \\
\hline Fam. Coenagrionidae & Epitheca bimaculata (Charpentier, 1825) \\
\hline Coenagrion puella (Linnaeus, 1758)** & $\begin{array}{l}\text { Somatochlora flavomaculata (Vander Linden, } \\
1825)^{*}\end{array}$ \\
\hline C. pulchellum (Vander Linden, 1825)* & Fam. Gomphidae \\
\hline $\begin{array}{l}\text { Enallagma cyathigerum (Charpentier, } \\
1840)^{* *}\end{array}$ & Gomphus vulgatissimus (Linnaeus, 1758) \\
\hline Erythromma najas (Hansemann, 1823) & Onychogomphus forcipatus (Linnaeus, 1758) \\
\hline Ischnura elegans (Vander Linden, 1820) & Fam. Libellulidae \\
\hline Ischnura pumilio (Charpentier, 1825)* & Crocothemis erythraea (Brullé, 1832) \\
\hline Pyrrhosoma nymphula (Sulzer, 1776)** & Leucorrhinia pectoralis (Charpentier, 1825)* \\
\hline Fam. Platycnemididae & Libellula depressa Linnaeus, $1758^{* *}$ \\
\hline \multirow[t]{11}{*}{ Platycnemis pennipes (Pallas, 1771)** } & Libellula quadrimaculata Linnaeus, 1758** \\
\hline & Orthetrum albistylum (Selys, 1848) \\
\hline & Orthetrum brunneum (Fonscolombe, 1837)** \\
\hline & Orthetrum cancellatum (Linnaeus, 1758) \\
\hline & Sympetrum depressiusculum (Selys, 1841)* \\
\hline & Sympetrum flaveolum (Linnaeus, 1758) ** \\
\hline & Sympetrum fonscolombii (Selys, 1840)** \\
\hline & Sympetrum meridionale (Selys, 1841)** \\
\hline & Sympetrum sanguineum (Müller, 1764) \\
\hline & Sympetrum striolatum (Charpentier, 1840) \\
\hline & Sympetrum vulgatum (Linnaeus, 1758)** \\
\hline
\end{tabular}

Without asterisk are findings of this research only, * literature sources only (ADAMOVIĆ, 1949, ANDJUS, 1992; SANTOVAC et al., 2005; JOVIĆ et al., 2009), ** literature sources and findings of this research.

Records from village Rogot (10 km from Kragujevac) in 1906 and Šumarice Lake in Kragujevac in 2006 were until now the southernmost records of E. bimaculata in Serbia (JOVIĆ et al., 2009). In Southwestren Bulgaria, GAINZARAIN (2017) photographed a young female in maturation on the Rila mountain and that is now the southernmost European record of this species. A sight finding of E. bimaculata in the area of Skadar Lake at the border of Montenegro and Albania provided, if correct, further information on the distribution of this species in the Mediterranean (DE KNIJF et al., 2013). In Serbia, E. bimaculata is protected by the Serbian Code of regulations on the declaration and protection of strictly protected and protected wild species of plants, animals and fungi: Appendix II Protected wild species of plants, animals and fungi (OGRS, 2010). 


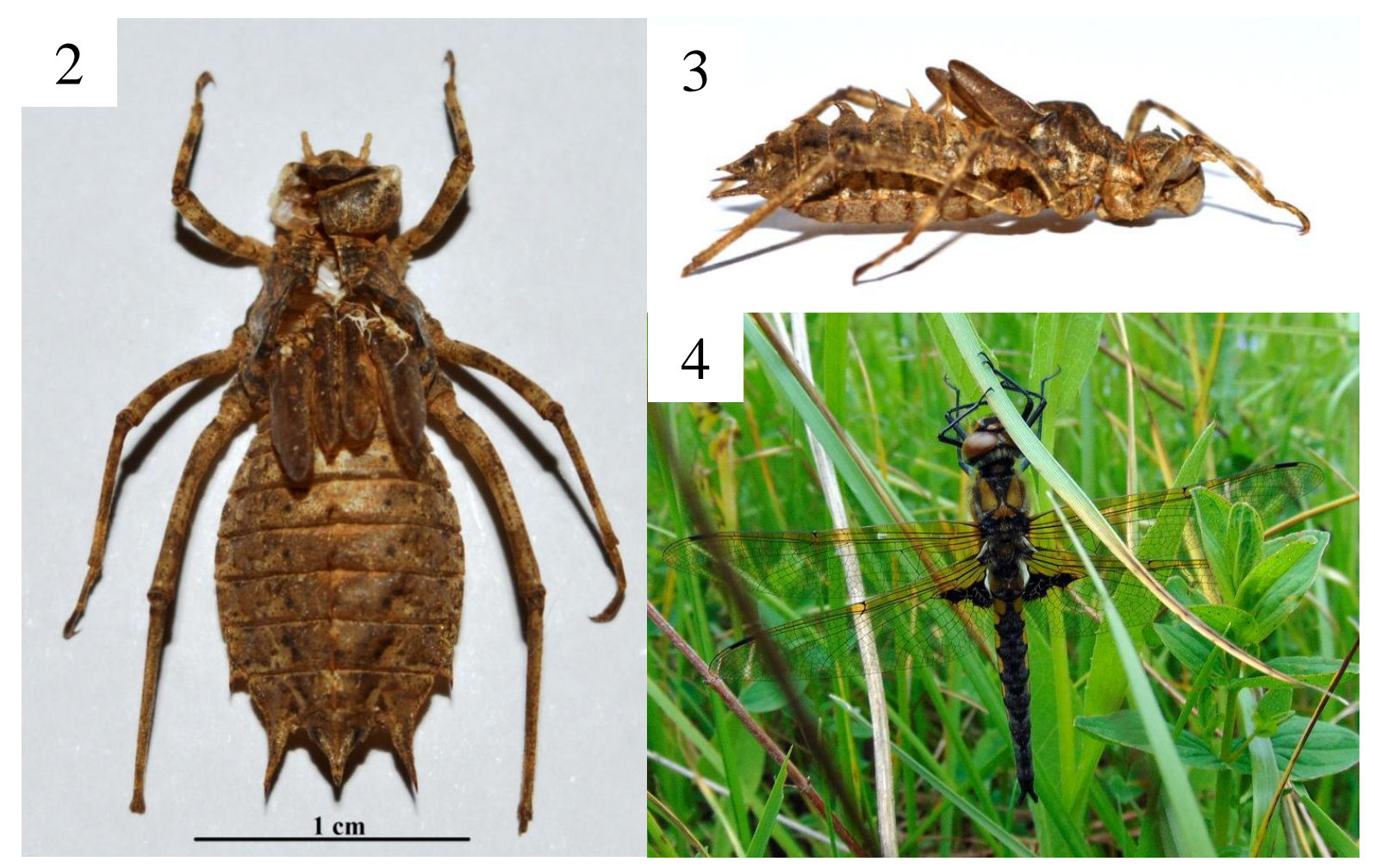

Figure 2-4. Epitheca bimaculata at Vlasina Rid (lake shoreline). 2) exuviae, dorsal view 3) exuviae, lateral view (Photo: Bojana Matić) 4) adult male (Photo: Milan Đurić).

\section{Sympetrum flaveolum}

Sympetrum flaveolum is a widespread species in Europe, especially in central and north-eastern regions of the continent. In the south of Europe S. flaveolum has sporadic distribution, with permanent presence only at higher altitudes (e.g. KALKMAN and KULIJER, 2015). This species inhabits shallow, often temporary flooded, well-vegetated waters that warm up quickly, such as grassy swampy depressions at lake margins and in seasonally flooded ponds in meadows (DIJKSTRA and LEWINGTON, 2006).

In the territory of the nearby Bosnia and Herzegovina S. flaveolum is abundant. Stable populations have been found at higher altitudes. The highest number of records comes from mountain areas that are above $700 \mathrm{~m}$ a.s.l. Karst polje with habitats that dry out during the summer make a typical biotope for S. flaveolum in this country (KULIJER, 2015). BESCHOVSKI and MARINOV (2007) reported that $S$. flaveolum is commonly found in mountainous areas of Bulgaria, while the sightings in lowland regions are sporadic.

Sympetrum flaveolum has been recorded in both lowland and mountainous parts of Serbia. Data on the species are rare and sporadic (ĐUKIĆ, 2014). More research is needed to determine the status of $S$. flaveolum in Serbia. In the LOF "Vlasina" S. flaveolum has been recorded every year of the studied period. Teneral individuals have been found along the southern, well vegetated coast of Vlasina lake (locality No. 13: Blato), which confirmes its presence as regularly breeding populations.

\section{Leucorrhinia pectoralis}

Leucorrhinia pectoralis is the largest species of the genus in Europe, with individuals ranging from 32 to $45 \mathrm{~mm}$ in body length. Its flight period spans between the end of April and early August, with peak season in late May-early June (ASKEw, 2004; DIJKSTRA and LEWINGTON, 2006). According to DiJKSTRA and LeWINGTON (2006) the species prefers 
marshy borders to bogs, forest lakes, fenlands, marshy ditches, oxbow lakes and even sluggish rivers or canals. Vegetation is typically dense and varied, with both emergent and submerged species. The water is frequently mesotrophic and often coloured brown due to peat and related humic acids. Typical habitat for this species are peatlands, a biotope that is in decline and in need of special protection in Europe (TATOLE, 2010). Due to its habitat specificity and its threatened status (BOUDOT et al., 2009; RANNAP et al., 2011), L. pectoralis is included in the Bern Convention (Appendix II) (COUNCIL OF EuROPE, 1979) and in the Habitats Directive (Annexes II and IV) (EUROPEAN COMMISSION, 1992). In Serbia this species is protected by the Code of regulations on the declaration and protection of strictly protected and protected wild species of plants, animals and fungi: Appendix II Protected wild species of plants, animals and fungi (OGRS, 2010).

Leucorrhinia pectoralis is a very rare species with Euro-Siberian distribution (ASKEW, 2004). It becomes increasingly local further south, with only scattered records in the Balkan penninsula, except Slovenia and Croatia (KALKMAN and MAUERSBERGER 2015). In Serbia it was recorded in just three localities. In the north of Vojvodina province, locality Hajdukovo (SANTOVAC, 2007) and oxbow Pana (JuRCA et al., 2009) and in the Vlasina region, far back in 1949 (ADAMOVIĆ, 1949). It was exactly in the year when formation (filling) of Vlasina lake started, and it lasted all the way to 1954. Submerging of more than 400 ha of mire caused destruction of the huge part of the optimal habitat for this species. Larvae of L. pectoralis are most active in daytime, when they are busy to hunt (TAGLIAPIETRA and ZANOCCO, 1998). That explains why survival of the larvae is strongly influenced by the presence of fish in localities where fish may access its larval habitats (NILSSON, 1981). SIMONOVIĆ and NIKOLIĆ (1996) registered 16 fish species in Vlasina Lake, five of them being allochthonous. According to JANKOVIĆ and RASPOPOVIĆ (1960), ichthyofauna of Vlasina consisted of three autochthonous species before dam construction: Salmo trutta, Barbus peloponnesius and Phoxinus phoxinus. Larger presence of fish and destruction of the best habitats for the species definitely affected negatively L. pecotralis.

Due to intensive anthropogenic influence there is a large probability that this species is extinct at Vlasina lake. Well vegetated, peaty shallows left only along a small part of the Vlasina lake's margins, together with the high amplitude of water level fluctuations and the presence of fish, most lilkely make it an unsuitable habitat for L. pectoralis, However, research certainly should be directed to search for this species, and if it is still present, conservation measures should be applied to secure survival of L. pectoralis population.

\section{CONCLUSION}

Dragonflies and damselflies are important indicators of the state and changes in the environment. This paper presents compiled data from literature and the results of this research. Between 2013 and 2018, 27 species of damselflies and dragonflies were recorded within the borders of the Landscape of outstanding features "Vlasina", and together with the previously published data we came up with a preliminary list of 37 species. These records contribute to the knowledge of the fauna and distribution of Odonata in the researched area, but also for territory of the entire Serbia. We present notes on some peculiar and important species: Epitheca bimaculata, Sympetrum flaveolum and Leucorrhinia pectoralis. By assessing their status of reproduction, we conclude that 12 species reproduce with certainty in the LOF "Vlasina". Further field observations will probably increase number of species with that status, while new species for the area can also be expected.

\section{Acknowledgments}


We are thankful to the managers of the Landscape of outstanding features "Vlasina" "Turistička organizacija opštine Surdulica" for providing technical support and accommodation. Also, we express gratitude to all those who kindly supplied their records. We are thankful to Milan Đurić and Milica Bekavac for language suggestions and corrections. The field surveys were made as a part of regular field studies by Scientic Research Society of Biology and Ecology Students "Josif Pančić" (Novi Sad) with visiting students from the Biology students association - BIUS (Zagreb), and Association for Sustainable Development and Habitat Protection in Serbia "HabiProt" (Belgrade).

\section{References:}

[1] AdAmOviĆ, Ž. (1949): Spisak vilinskih konjica (Odonata FABR.) u Prirodnjačkom muzeju Srpske zemlje. Glasnik Prirodnjačkog muzeja Srpske zemlje 1(2): 275-293.

[2] AdAmović, Ž. (1993): Distribution of Odonata at Krupačko Jezero, Serbia. Bulletin de l'Académie Serbe des Sciences et Arts, Sciences naturelles 34: 9-22.

[3] AdAmovic, Ž., ANDus, LJ. (1983): Odonata in the area of Obedska Bara. In: Anonymus: Zaštita, uređivanje i unapređenje Obedske bare. Pokrajinski zavod za zaštitu prirode, Novi Sad, 47-50 pp. [in Serbian]

[4] ANDJus, LJ. (1992): New data on the distribution of Odonata in Serbia. Bulletin of the Natural History Museum Belgrade (Ser.) 47: 149-170.

[5] Askew, R.R. (2004): The Dragonflies of Europe - revised edition. Harley Books (UK): $308 \mathrm{pp}$.

[6] BeLIJ, S. (2014): Landscape of outstanding features Vlasina. Institute for Nature Conservation of Serbia, PE Surdulica Municipality Land Development Directorate, Belgrade, $155 \mathrm{pp}$.

[7] Beschovski, V., Marinov, M. (2007): Fauna, Ecology, and Zoogeography of Dragonflies (Insecta: Odonata) of Bulgaria. In: Fet, V. and Popov, A. (eds). Biogeography and Ecology of Bulgaria. Dordrecht (UK), Springer, 199-231 pp.

[8] Boudot J.P., KalKman V.J. (2015): Atlas of the European dragonflies and damselflies. Netherlands, KNNV publishers, $381 \mathrm{pp}$.

[9] Boudot, J.P., KAlKman, V.J., AzPilicueta Amorín, M., Bogdanović, T., Cordero Rivera, A., Degabriele, G., Dommanget, J.L., Ferreira, S., Garrigós, B., Jović, M., Kotarac, M., Lopau, W., Marinov, M., Mihoković, N., Riservato, E., SAMraoui, B., SchneIDER, W. (2009): Atlas of the Odonata of the Mediterranean and North Africa. Libellula Supplement 9: 1-256.

[10] CounCIL OF EUROPE (1979): Convention on the Conservation of European Wildlife and Natural Heritage. Bern, Switzerland. https://www.coe.int/en/web/conventions/ search-on-treaties/-/conventions/treaty/104 Accessed 20 December 2018.

[11] Daguet, C.A., French, G.C., TAYloR, P. (2008): The Odonata Red Data List for Great Britain. Species Status 11: 1-34.

[12] De Knijf, G., Vanappelghem, C., Demolder, H. (2013): Odonata from Montenegro, with notes on taxonomy, regional diversity and conservation. Odonatologica 42: 1-29.

[13] DijkstrA, K.D.B., Lewington, R. (2006): Field Guide to the Dragonflies of Britain and Europe. Milton Stour (UK), British Wildlife Publishing, 320 pp.

[14] Dinov, J., CRnobrnja Isailović, J. (2013): Species richness of amphibian and reptile fauna on Vlasina plateau. 11thSymposium on the flora of southeastern Serbia and neighboring regions, Vlasina lake, Serbia, June 13th-16th 2013, Abstract Book, 123 pp. 
[15] Đukić, A. (ed) (2014): Alciphron - Database on insects of Serbia (Odonata), Habiprot. http://alciphron.habiprot.org.rs Accessed 30 November 2018.

[16] EuROPEAN COMMISSION (1992): Council Directive 92/43/EEC of 21 May 1992 on the conservation of natural habitats and of wild fauna and flora. Official Journal of the European Communities. No L 206/7.

[17] GAINZARAIN, J.A. (2017): Epitheca bimaculata - a new species for the fauna of Bulgaria (Odonata: Corduliidae). Notulae odonatologicae 8(10): 369-392.

[18] JankoviĆ, D., RAspopoviĆ, M. (1960): Ohrid Lake trout (Salmoletnica typicus K.) under altered conditions in the Lake Vlasina Reservoir. Archives of Biological Sciences 12: 117-122.

[19] Jović, M. (2013): A proposal of Serbian names for dragonfly species (Insecta: Odonata) of the Balkan Peninsula, with the checklist of Odonata of Serbia. Acta entomologica Serbica 18(1/2): 1-10.

[20] Jović, M., ANDJUS, LJ. (2003): Epitheca bimaculata (Charpentier) recorded from Serbia again (Odonata: Corduliidae). Opuscula zoologica fluminense 214: 1-7.

[21] Jović, M., Anduus, LJ., Santovac, S. (2009): New data on some rare and poorly known Odonata species in Serbia. Bulletin of the Natural History Museum 2: 95-108.

[22] Jović, M., Stanković, M., Santovac, S. (2007): First contribution to knowledge on Odonata of Special Nature Reserve Zasavica. Naučno-stručni skup „Zasavica 2007” sa međunarodnim učešćem, Zbornik radova: 59-66. [in Serbian, with English summary]

[23] Jurca, T., Sabadoš, K., Miljanović, B., ŠIPoš, Š., Horvatović, M., Perić, R., ŠĆIBAN, M., JANKOVIĆ, M. (2009): Wetlands as important habitats for biodiversity conservation: Oxbow Pana key study. Protection of Nature 60(1-2): 337-347.

[24] Kalkman, V.J., Mauersberger, R. (2015). Leucorrhinia pectoralis. In Boudot, J.P. and Kalkman, V.J. (eds), Atlas of the European Dragonflies and Damselflies. KNNV, Utrecht, 264-265 pp.

[25] KociĆ, D. (2018): EPS drastično spustio nivo Vlasinskog jezera. Politika. http://www.politika.rs/sr/clanak/412494/EPS-drasticno-spustio-nivo-Vlasinskog-jezera Accessed 1 April 2019.

[26] KuliJER, D. (2015): Sympetrum flaveolum in the Dinaric Alps (Odonata: Libellulidae). Libellula 34(1/2): 91-101.

[27] Monnerat, C. (2005): Epitheca bimaculata (Charpentier 1825). In: Wildermuth, H., Gonseth, Y., Maibach, A.(eds) Odonata - Les Libellules de Suisse. Neuchâtel (CH): CSCF/SES, 267-269 pp.

[28] NiLSSON, B.I. (1981): Susceptibility of some Odonata larvae to fish predation. Verhandlungen des Internationalen Verein Limnologie 21: 1612-1615.

[29] [OGRS] Official Gazette of RS. (2010): Code of regulations on the declaration and protection of strictly protected and protected wild species of plants, animals and fungi (no. 5/2010).

[30] PavićEvić, D., IVković, S., HoRvat, L. (2014): New and rare species of orthopteroid insects in the fauna of Serbia. Fauna Balkana 3: 103-122.

[31] Puzović, S., Sekulić, G., Stojnić, N., Grubač, B., Tucakov, M. (2009): Important Bird Areas in Serbia. Ministry of Environment and Spatial Planning, Institute for Nature Conservation of Serbia, Provincial Secretariat of Environmental Protection and Sustainable Development, Belgrade, 278 pp.

[32] RAJKov, S. (2014): Odonata fauna of urban area of Novi Sad. Novi Sad. University of Novi Sad, Faculty of Science, Department of biology and ecology, 71 pp. [in Serbian] 
[33] RajKov, S. (2016): The second overview of dragonfly (Odonata) fauna of the OvčarKablar Gorge. Beležnik Ovčarsko-kablarske klisure 6 (1): 20-29. [in Serbian]

[34] RAJKov, S., ŠćiBAN, M. (2012): Contribution to knowledge on Odonata of "Zasasvica" SNR. In: Simić, S. (eds). Zbornik naučno-stručnog skupa "Zasavica 2012”. Pokret Gorana Sremska Mitrovica, 154-161. [in Serbian]

[35] Rajkov, S., Vinko, D., ARANĐEloviĆ, A. (2012): Faunistic results from the $2^{\text {nd }}$ Balkan OdonatOlogical Meeting - BOOM. Natura Sloveniae 17(2): 67-76.

[36] RanĐelović, V.N., Zlatković, K.B. (2010): Flora and vegetation of Vlasinsa plateau. Nis (SRB): Faculty of Sciences and Mathematics - University of Nis, 448 pp. [in Serbian with English summary]

[37] Rannap, R., KaART, T., Briggs L., DE VRIES, W. (2011): Habitat requirements of Pelobates fuscus and Leucorrhinia pectoralis. Project report: "Securing Leucorrhinia pectoralis and Pelobates fuscus in the northern distribution area in Estonia and Denmark". LIFE08NAT/EE/000257, Tallinn, 23 pp.

[38] Santovac, S. (2007): Fauna of Odonata (Insecta) of Vojvodina. MSc Thesis (manuscr.), University of Novi Sad, Faculty of Sciences and Mathematics, Deparment of Biology and Ecology, Novi Sad, 174 pp. [in Serbian]

[39] Santovac, S., AnĐUs, LJ., (1995-98): The first survey of the fauna of Odonata in special nature reserve "Stari Begej - Carska Bara". Bulletin of the Natural History Museum in Belgrade 49-50: 157-165.

[40] Santovac, S., Jovic, M., Andus, LJ. (2005): Sympetrum depressiusculum (Sélys, 1841) new species in the Odonata fauna of Serbia. Archives of Biological Sciences. Belgrade, 57(3): 15-16.

[41] Simonović, P., Nikolić, V. (1996): Ichthyofauna of the Vlasinsko jezero reservoir. In: Blaženčić, J. (ed). Vlasinsko Jezero reservoir hydrobiological study Belgrade (SRB): Faculty of Biology, Beograd, 179-196 pp.

[42] Skejo, J., Ivković, S. (2015): Chorthippus bornhalmi in the heart of the Balkans (Acrididae: Gomphocerinae). Articulata 30: 81-90.

[43] Stankovic, S. (1970): Kolebanje nivoa vode veštačkih jezera Srbije i mogućnosti izgradnje turističkih objekata. Hrvatski geografski glasnik 32 (1): 181-186.

[44] ŠEAT, J. (2017): Contribution to the knowledge on true bugs (Insecta: Heteroptera) of Vlasina. Zaštita prirode 67(1-2): 43-54. [in Serbian with English summary]

[45] Tagliapietra, V., Zanocco, D. (1998): Il Progetto Bioitaly in Trentino: invertebrati. Centro di Ecologia Alpina, Trento-Viote del Monte Bondone, Report n. 14: 83 pp.

[46] TAtole, V. (2010): Managementul şi monitoringul speciilor de animale Natura 2000 din România - Ghid metodologic. Ed. Excelsior Print Bucureşti, 329 pp.

[47] Tot, I., Slacki, A., Đurić, M., Popović, M. (2015): Butterflies of the Vlasina Region in Southeast Serbia (Lepidoptera: Papilionoidea). Acta entomologica serbica 20: 117135.

[48] Tot, T., Vujić, M., Likov, L., Nedeljković, Z., Radenković, S., Vujić, A. (2018): Hoverfly fauna (Diptera: Syrphidae) of the Landscape of Outstanding Features „Vlasina“. Acta etomologica serbica 23: 33-50.

[49] Vujić, M., NedeluKović, Z., Tot, T. (2016): Arctophila bequaerti Hervé-Bazin (Diptera: Syrphidae), new to the Serbian fauna. Studia dipterologica 23(2): 162-164. 